\title{
Genetic Diversity of Japanese Strains of Ralstonia solanacearum
}

\author{
Mitsuo Horita and Kenichi Tsuchiya
}

National Institute of Agrobiological Resources, Kannondai 2-1-2, Tsukuba 305-8602, Japan.

Accepted for publication 22 December 2000.

\begin{abstract}
Horita, M., and Tsuchiya, K. 2001. Genetic diversity of Japanese strains of Ralstonia solanacearum. Phytopathology 91:399-407.

The genetic diversity of 74 Japanese strains of Ralstonia solanacearum was assessed by pathogenicity tests and the repetitive sequencebased polymerase chain reaction (rep-PCR) fingerprint method. Based on their genomic fingerprints, biovar N2 strains were divided into two distinct groups, one consisting of potato isolates belonging to race 3 , and the other consisting of tomato, eggplant, pepper, and tobacco isolates

belonging to race 1 . Biovar 3 strains had low average similarity and were divided into five groups that differed in original host or pathogenicity. Biovar 4 strains consisted of only one group at the $80 \%$ similarity level. Comparative analysis of the rep-PCR fingerprints of 78 strains, including six biovars from Japan and various countries, revealed two main clusters. Cluster 1 comprised all biovar 3, 4, and 5 strains, biovar 1 strains from Reunion, and some biovar N2 strains from Japan. Cluster 2 included most of the biovar 1,2, and N2 strains. The fingerprints showed low average similarity with biovar N2 strains from Japan and Brazil.
\end{abstract}

Ralstonia solanacearum (synonym Pseudomonas) (43,49) causes a lethal wilting disease on many important crops in tropical, subtropical, and warm regions in the world. The host range of the bacterium is exceptionally wide, and many economically important crops as well as many weed hosts have been recognized (16). $R$. solanacearum is a diverse species that differs in host range, geographical distribution, pathogenicity, epidemiological relationships, and physiological properties. To describe this intraspecific variability, binary classification systems are used. This pathogen is divided into five races $(2,19,39)$ based on host range and six biovars $(14,17,19)$ based on utilization of three disaccharides and three hexose alcohols. In Japan, bacterial wilt disease caused by $R$. solanacearum has been reported mainly for solanaceous crops including tomato (Lycopersicon esculentum Mill), potato (Solanum tuberosum L.), tobacco (Nicotiana tabacum L.), eggplant (S. melongena L.), and sweet pepper (Capsicum annuum L.). To date, more than 34 species in 18 families of plants have been reported as hosts in Japan $(6,40)$. The classification of Japanese strains of $R$. solanacearum has been studied by several workers $(24,33-35,37)$. However, the systematic relationship among strains is still poorly defined. Analysis of genetic diversity is important for understanding the distribution of strains worldwide and prevention of their further dissemination.

Recently, DNA-based analyses (restriction fragment length polymorphism [RFLP], 16S rDNA sequence, repetitive sequencebased polymerase chain reaction [rep-PCR], etc.) are effective in assessing the diversity and genetic relationships among $R$. solanacearum strains $(3-5,9,11,23,26,41,42,44,47)$. The objectives of this study were to determine the pathogenic variation among Japanese strains of $R$. solanacearum and to compare them with strains of geographically diverse origin by the repPCR fingerprint method. The rep-PCR method uses primer sets based on conserved repetitive bacterial elements referred to as enterobacterial repetitive intergenic consensus (ERIC) (22), repetitive extragenic palindromic (REP) (12), and BOX (32). PCR

Corresponding author: M. Horita; E-mail address: mhorita@ abr.affrc.go.jp

Publication no. P-2001-0123-01R

(c) 2001 The American Phytopathological Society amplification by these primer sets can yield genomic fingerprints specific to pathovars or strains of phytopathogenic bacteria $(9,23,27-29,44)$.

\section{MATERIALS AND METHODS}

Bacterial strains and growing conditions. Bacterial strains used in this study are listed in Table 1. Most strains were from the Ministry of Agriculture, Forestry, and Fisheries, Japan (MAFF) Genebank culture collection. Thirteen strains from outside Japan were derived from the National Center for Agricultural Research, Ghent, Belgium. All strains were maintained in long-term storage as suspensions in sterile distilled water or by freezing in a medium containing $10 \%$ skimmed milk supplemented with $1 \%$ sodium glutamate at $-30^{\circ} \mathrm{C}$, and were revived by plating on tetrazolium chloride (TZC) medium (25). For tests, strains were grown at $30^{\circ} \mathrm{C}$ on TZC medium or casamino acids, peptone, and glucose (CPG) broth (20) on a rotary shaker at $150 \mathrm{rpm}$.

Pathogenicity, hypersensitivity tests, and biovar determination. For the pathogenicity test, tomato (cv. Houkin No. 2), eggplant (cv. Senryo No. 2), sweet pepper (cv. Wase Green), potato (cv. Danshaku), and tobacco (cv. Bright Yellow No. 4) were used. Seedlings were transplanted in plastic pots $(8-\mathrm{cm}$ diameter) containing a horticultural soil-vermiculite mixture, and grown in a greenhouse at 25 to $30^{\circ} \mathrm{C}$. To prepare inoculum, bacteria were grown on TZC agar for 2 to 3 days at $30^{\circ} \mathrm{C}$, suspended in sterile distilled water, and adjusted to $10^{9} \mathrm{CFU} / \mathrm{ml}$. Plants at the fourth to fifth true-leaf stage were inoculated by puncturing the basal part of the stem with a needle dipped in inoculum (48). Two to four plants of each host were inoculated with each strain. Inoculated plants were placed in the greenhouse at 25 to $30^{\circ} \mathrm{C}$ under natural light. Severity of wilting was observed at weekly intervals on the following scale: $1=$ no symptom, $2=$ leaf above inoculation site wilted, $3=$ two or three leaves wilted, $4=$ four or more leaves wilted, and $5=$ plant dead. The inoculation test was repeated two or more times on separate days. The hypersensitivity (HR) test was done as described by Lozano and Sequeira (30). Bacterial suspensions $\left(\approx 10^{8} \mathrm{CFU} / \mathrm{ml}\right)$ were infiltrated into fully expanded tobacco leaves (cv. Bright Yellow No. 4). The reaction was recorded at 24,48 , and $72 \mathrm{~h}$ after infiltration. Biovar and the utilization of trehalose, meso-inositol, 
and D-ribose were determined by the methods of Hayward $(14,15)$. Growth and acid production from carbohydrates were observed. Nitrite and gas production from nitrate were determined according to the method of Hayward et al. (18).

rep-PCR analysis. The rep-PCR method employed was adapted from Louws et al. (28). The primer sets: REP, REP1R-I (5'-III ICG ICG ICA TCI GGC-3') and REP2-I (5'-ICG ITT ATC IGG CCT AC-3'); ERIC, ERIC1R (5'-ATG TAA GCT CCT GGG GAT TCA C-3') and ERIC2 (5'-AAG TAA GTG ACT GGG GTG AGC G-3'); and BOX, BOXA1R (5'-CTA CGG CAA GGC GAC
GCT GAC G-3') (28) were synthesized by Amersham Pharmacia Biotech (Tokyo, Japan). PCR amplifications were performed in a thermocycler (PC-800; Astec Inc., Tokyo, Japan) in 25- $\mu$ l reaction volumes of $10 \mathrm{mM}$ Tris- $\mathrm{HCl}$ at $\mathrm{pH} 8.3,50 \mathrm{mM} \mathrm{KCl}, 1.5 \mathrm{mM}$ $\mathrm{MgCl}_{2}, 200 \mu \mathrm{M}$ each dNTP, 50 pmol each primer, 2.5 unit of DNA polymerase Takara Taq (Takara Shuzo Co., Otsu, Japan), and $50 \mathrm{ng}$ of template DNA overlaid with $25 \mu \mathrm{l}$ of mineral oil (Sigma Chemical Co., St. Louis). The PCR thermocycler was programmed as follows: an initial denaturation step of $95^{\circ} \mathrm{C}$ for $7 \mathrm{~min}$, followed by 30 cycles of $94^{\circ} \mathrm{C}$ for $1 \mathrm{~min}, 44^{\circ} \mathrm{C}$ (REP) or

TABLE 1. Strains of Ralstonia solanacearum used in this study and classifications established according to race and biovar ${ }^{\mathrm{a}}$

\begin{tabular}{|c|c|c|c|c|c|c|}
\hline Code no. & Strain & Host & Geographical origin & Race & Biovar & Source $^{b}$ \\
\hline 1 & MAFF 211282 & Solanum melongena & Kochi, Japan & 1 & 3 & MAFF \\
\hline 2 & MAFF 301069 & Nicotiana tabacum & Shizuoka, Japan & 1 & 3 & MAFF \\
\hline 3 & MAFF 301070 & Lycopersicon esculentum & Kochi, Japan & 1 & 3 & MAFF \\
\hline 4 & MAFF 301522 & Lycopersicon esculentum & Kagoshima, Japan & 1 & 3 & MAFF \\
\hline 5 & MAFF 301560 & Strelitzia reginae & Nagasaki, Japan & 1 & 3 & MAFF \\
\hline 6 & MAFF 301561 & Strelitzia reginae & Nagasaki, Japan & 1 & 3 & MAFF \\
\hline 7 & MAFF 301841 & Solanum melongena & Kanagawa, Japan & 1 & 3 & MAFF \\
\hline 8 & MAFF 301849 & Capsicum anпиит & Tochigi, Japan & 1 & 3 & MAFF \\
\hline 9 & MAFF 301860 & Capsicum аппиит & Ibaraki, Japan & 1 & 3 & MAFF \\
\hline 10 & MAFF 302549 & Limonium sp. & Kochi, Japan & 1 & 3 & MAFF \\
\hline 11 & MAFF 302550 & Limonium sp. & Kochi, Japan & 1 & 3 & MAFF \\
\hline 12 & MAFF 302551 & Limonium sp. & Kochi, Japan & 1 & 3 & MAFF \\
\hline 13 & Ps29 & Nicotiana tabacum & Okayama, Japan & 1 & 3 & H. Hara \\
\hline 14 & U7 & Nicotiana tabacum & Tochigi, Japan & 1 & 3 & H. Hara \\
\hline 15 & U108 & Nicotiana tabacum & Kagoshima, Japan & 1 & 3 & H. Hara \\
\hline 16 & U137 & Nicotiana tabacum & Kagoshima, Japan & 1 & 3 & H. Hara \\
\hline 17 & $\mathrm{U} 154$ & Nicotiana tabacum & Kochi, Japan & 1 & 3 & H. Hara \\
\hline 18 & $\mathrm{U} 158$ & Nicotiana tabacum & Yamagata Japan & 1 & 3 & H. Hara \\
\hline 19 & U164 & Nicotiana tabacum & Tochigi, Japan & 1 & 3 & H. Hara \\
\hline 20 & U193 & Nicotiana tabacum & Fukushima, Japan & 1 & 3 & H. Hara \\
\hline 21 & $\mathrm{U} 247$ & Nicotiana tabacum & Niigata, Japan & 1 & 3 & H. Hara \\
\hline 22 & $\mathrm{U} 248$ & Nicotiana tabacum & Yamagata Japan & 1 & 3 & H. Hara \\
\hline 23 & $\mathrm{~K} 1$ & Kalanchoe sp. & Kagawa Japan & 1 & 3 & This study \\
\hline 24 & $\mathrm{~K} 2$ & Kalanchoe sp. & Kagawa Japan & 1 & 3 & This study \\
\hline 25 & MAFF 211266 & Lycopersicon esculentum & Hiroshima, Japan & 1 & $4 *$ & MAFF \\
\hline 26 & MAFF 211267 & Lycopersicon esculentum & Shimane, Japan & 1 & $4 *$ & MAFF \\
\hline 27 & MAFF 211268 & Solanum melongena & Kochi, Japan & 1 & 4 & MAFF \\
\hline 28 & MAFF 211269 & Solanum melongena & Nara, Japan & 1 & 4 & MAFF \\
\hline 29 & MAFF 211281 & Solanum melongena & Kochi, Japan & 1 & 4 & MAFF \\
\hline 30 & MAFF 301067 & Solanum melongena & Kanagawa, Japan & 1 & 4 & MAFF \\
\hline 31 & MAFF 301068 & Lycopersicon esculentum & Shizuoka, Japan & 1 & 4 & MAFF \\
\hline 32 & MAFF 301418 & Lycopersicon esculentum & Fukui, Japan & 1 & 4 & MAFF \\
\hline 33 & MAFF 301489 & Lycopersicon esculentum & Oita, Japan & 1 & 4 & MAFF \\
\hline 34 & MAFF 301491 & Lycopersicon esculentum & Oita, japan & 1 & 4 & MAFF \\
\hline 35 & MAFF 301520 & Solanum melongena & Saitama, Japan & 1 & 4 & MAFF \\
\hline 36 & MAFF 301521 & Solanum melongena & Nara, Japan & 1 & 4 & MAFF \\
\hline 37 & MAFF 301523 & Solanum melongena & Tokyo, Japan & 1 & 4 & MAFF \\
\hline 38 & MAFF 301524 & Solanum tuberosum & Nara, Japan & 1 & 4 & MAFF \\
\hline 39 & MAFF 301526 & Lycopersicon esculentum & Ibaraki, Japan & 1 & 4 & MAFF \\
\hline 40 & MAFF 301528 & Lycopersicon esculentum & Gunma, Japan & 1 & 4 & MAFF \\
\hline 41 & MAFF 301556 & Solanum tuberosum & Nagasaki, Japan & 1 & 4 & MAFF \\
\hline 42 & MAFF 301557 & Solanum tuberosum & Nagasaki, Japan & 1 & 4 & MAFF \\
\hline 43 & MAFF 301819 & Solanum melongena & Shizuoka, Japan & 1 & 4 & MAFF \\
\hline 44 & MAFF 301823 & Capsicum аппиит & Kochi, Japan & 1 & 4 & MAFF \\
\hline 45 & MAFF 301826 & Lycopersicon esculentum & Hiroshima, Japan & 1 & 4 & MAFF \\
\hline 46 & MAFF 301827 & Lycopersicon esculentum & Hiroshima, Japan & 1 & 4 & MAFF \\
\hline 47 & MAFF 301829 & Lycopersicon esculentum & Gifu, Japan & 1 & 4 & MAFF \\
\hline 48 & MAFF 301840 & Solanum melongena & Kanagawa, Japan & 1 & 4 & MAFF \\
\hline 49 & MAFF 301846 & Solanum tuberosum & Hokkaido, Japan & 1 & 4 & MAFF \\
\hline 50 & MAFF 301851 & Solanum melongena & Shizuoka, Japan & 1 & 4 & MAFF \\
\hline 51 & MAFF 301852 & Solanum melongena & Shizuoka, Japan & 1 & 4 & MAFF \\
\hline 52 & MAFF 301853 & Lycopersicon esculentum & Shizuoka, Japan & 1 & 4 & MAFF \\
\hline 53 & MAFF 301859 & Lycopersicon esculentum & Niigata, Japan & 1 & 4 & MAFF \\
\hline 54 & $89 \mathrm{C}-9$ & Cucurbita maxima $\times$ C. moschata & Okayama, Japan & 1 & 4 & H. Date \\
\hline 55 & $89 \mathrm{C}-10$ & Cucumis sativus & Okayama, Japan & 1 & 4 & H. Date \\
\hline 56 & MAFF 211280 & Solanum melongena & Kochi, Japan & 1 & N2 & MAFF \\
\hline 57 & MAFF 301485 & Lycopersicon esculentum & Oita, Japan & 1 & $\mathrm{~N} 2$ & MAFF \\
\hline
\end{tabular}

a $*$ Indicates reconfirmed in this study; $\mathrm{nt}=$ not tested.

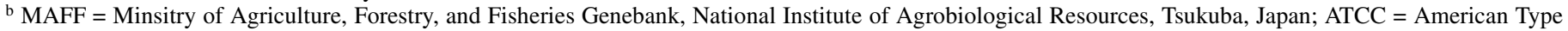
Culture Collection, Rockville, MD; NCAR = National Center for Agricultural Research, Ghent, Belgium; and UPLB = University of the Philippines, Los Baños. 
$52^{\circ} \mathrm{C}$ (ERIC, BOX) for $1 \mathrm{~min}$, and $65^{\circ} \mathrm{C}$ for $8 \mathrm{~min}$ with a final extension step of $65^{\circ} \mathrm{C}$ for $15 \mathrm{~min}$. Amplified PCR products (4 to $8 \mu \mathrm{l})$ were separated by $1.5 \%$ agarose gel electrophoresis in $0.5 \times$ Tris-acetate-EDTA buffer ( $89 \mathrm{mM}$ Tris-acetate, $\mathrm{pH} 8.0$, and $2 \mathrm{mM}$ EDTA) at $4 \mathrm{~V} / \mathrm{cm}$ for $5 \mathrm{~h}$, stained with ethidium bromide, and photographed under UV light. For the confirmation of banding patterns, rep-PCR experiments were repeated at least two times with independently prepared DNA stocks.

Data analysis. The rep-PCR fingerprint profiles were used to measure genetic similarity among strains. Each band with a dif- ferent electrophoretic mobility was assigned a position number and scored as either 1 or 0 based on the presence or absence of the band, respectively, for this position. The similarity coefficients for all possible pairs of strains based on the fingerprint groups was estimated by the Dice method (7). Dendrograms were constructed from the similarity coefficient data by the unweighted pair group method with arithmetic averages clustering (45).

To evaluate the robustness of the groupings formed, the binary data set was subjected to bootstrapping. Using the WinBoot software program (50), the phenogram was reconstructed 2,000 times

TABLE 1. (continued from preceding page)

\begin{tabular}{|c|c|c|c|c|c|c|}
\hline Code no. & Strain & Host & Geographical origin & Race & Biovar & Source $^{b}$ \\
\hline 58 & MAFF 301486 & Lycopersicon esculentum & Oita, Japan & 1 & $\mathrm{~N} 2$ & MAFF \\
\hline 59 & MAFF 301487 & Lycopersicon esculentum & Oita, Japan & 1 & $\mathrm{~N} 2$ & MAFF \\
\hline 60 & MAFF 301488 & Lycopersicon esculentum & Oita, Japan & 1 & $\mathrm{~N} 2$ & MAFF \\
\hline 61 & MAFF 301492 & Solanum melongena & Oita, Japan & 1 & $\mathrm{~N} 2$ & MAFF \\
\hline 62 & MAFF 301527 & Capsicum annuum & Oita, Japan & 1 & $\mathrm{~N} 2$ & MAFF \\
\hline 63 & Ps 27 & Nicotiana tabacum & Okayama, Japan & 1 & $\mathrm{~N} 2$ & H. Hara \\
\hline 64 & MAFF 211271 & Solanum tuberosum & Shizuoka, Japan & 3 & $\mathrm{~N} 2$ & MAFF \\
\hline 65 & MAFF 301558 & Solanum tuberosum & Nagasaki, Japan & 3 & $\mathrm{~N} 2$ & MAFF \\
\hline 66 & MAFF 301559 & Solanum tuberosum & Nagasaki, Japan & 3 & $\mathrm{~N} 2$ & MAFF \\
\hline 67 & SUPP 1917 & Solanum tuberosum & Nagasaki, Japan & 3 & $\mathrm{~N} 2$ & Y. Takikawa \\
\hline 68 & AA3122 & Solanum tuberosum & Nagasaki, Japan & 3 & $\mathrm{~N} 2$ & Y. Suga \\
\hline 69 & AA6002 & Solanum tuberosum & Nagasaki, Japan & 3 & $\mathrm{~N} 2$ & Y. Suga \\
\hline 70 & AA6004 & Solanum tuberosum & Nagasaki, Japan & 3 & $\mathrm{~N} 2$ & Y. Suga \\
\hline 71 & AA6009 & Solanum tuberosum & Nagasaki, Japan & 3 & $\mathrm{~N} 2$ & Y. Suga \\
\hline 72 & AA6011 & Solanum tuberosum & Nagasaki, Japan & 3 & $\mathrm{~N} 2$ & Y. Suga \\
\hline 73 & AA6012 & Solanum tuberosum & Nagasaki, Japan & 3 & $\mathrm{~N} 2$ & Y. Suga \\
\hline 74 & AA7001 & Solanum tuberosum & Nagasaki, Japan & 3 & $\mathrm{~N} 2$ & Y. Suga \\
\hline 75 & ATCC $11696^{\mathrm{T}}$ & Lycopersicon esculentum & United States & 1 & 1 & ATCC \\
\hline 76 & PD 1938 & Lycopersicon esculentum & United States & 1 & 1 & NCAR \\
\hline 77 & PD 1940 & Pelargonium capitatum & Reunion & 1 & 1 & NCAR \\
\hline 78 & $2146 c$ & Pelargonium capitatum & Reunion & 1 & 1 & S. Poussier \\
\hline 79 & 13 & Solanum tuberosum & Brasilia, Brazil & 1 & 1 & N. Furuya \\
\hline 80 & 629 & Capsicum anпиит & Para, Brazil & 1 & 1 & N. Furuya \\
\hline 81 & 574 & Eucalyptus sp. & Para, Brazil & 1 & 1 & N. Furuya \\
\hline 82 & 656 & Cucumis sp. & Amazonas, Brazil & 1 & 1 & N. Furuya \\
\hline 83 & PD 1445 & Musa sp. & Panama & 2 & 1 & NCAR \\
\hline 84 & PD 1446 & Heliconia sp. & Costa Rica & 2 & 1 & NCAR \\
\hline 85 & MoD3 & Musa sp. & Philippines & 2 & 1 & UPLB \\
\hline 86 & BuD4 & Musa sp. & Philippines & 2 & 1 & UPLB \\
\hline 87 & PD 1939 & Solanum tuberosum & Israel & 3 & 2 & NCAR \\
\hline 88 & PD 441 & Solanum tuberosum & Sweden & 3 & 2 & NCAR \\
\hline 89 & PD 1260 & Solanum tuberosum & Reunion & 3 & 2 & NCAR \\
\hline 90 & PD 1100 & Solanum tuberosum & Egypt & 3 & 2 & NCAR \\
\hline 91 & PD 1610 & Solanum tuberosum & Belgium & 3 & 2 & NCAR \\
\hline 92 & 113 & Lycopersicon esculentum & Parana, Brazil & 3 & 2 & N. Furuya \\
\hline 93 & 855 & Solanum tuberosum & Brasilia, Brazil & 3 & 2 & N. Furuya \\
\hline 94 & TK1-3-1 & Solanum tuberosum & Thailand & 3 & 2 & This study \\
\hline 95 & Garut 1 & Solanum tuberosum & Indonesia & 3 & 2 & K. Katayama \\
\hline 96 & Garut 2 & Solanum tuberosum & Indonesia & 3 & 2 & K. Katayama \\
\hline 97 & BBU1 & Solanum tuberosum & Indonesia & 3 & 2 & K. Katayama \\
\hline 98 & BBU2 & Solanum tuberosum & Indonesia & 3 & 2 & K. Katayama \\
\hline 99 & R568 & Solanum tuberosum & Brazil & nt & $\mathrm{N} 2$ & NCAR \\
\hline 100 & 61 & Solanum tuberosum & Parana, Brazil & $\mathrm{nt}$ & $\mathrm{N} 2$ & N. Furuya \\
\hline 101 & 66 & Solanum tuberosum & Minas Gerais, Brazil & $\mathrm{nt}$ & $\mathrm{N} 2$ & N. Furuya \\
\hline 102 & 67 & Solanum tuberosum & Bahia, Brazil & nt & $\mathrm{N} 2$ & N. Furuya \\
\hline 103 & 71 & Solanum tuberosum & Brasilia, Brazil & nt & $\mathrm{N} 2$ & N. Furuya \\
\hline 104 & 92 & Solanum tuberosum & Brasilia, Brazil & nt & $\mathrm{N} 2$ & N. Furuya \\
\hline 105 & 98 & Solanum tuberosum & Santa Catarina, Brazil & nt & $\mathrm{N} 2$ & N. Furuya \\
\hline 106 & 933 & Solanum tuberosum & Brasilia, Brazil & $\mathrm{nt}$ & $\mathrm{N} 2$ & N. Furuya \\
\hline 107 & 964 & Solanum tuberosum & Santa Catarina, Brazil & $\mathrm{nt}$ & $\mathrm{N} 2$ & N. Furuya \\
\hline 108 & 982 & Solanum tuberosum & Rio de Janeiro, Brazil & nt & $\mathrm{N} 2$ & N. Furuya \\
\hline 109 & MAFF 211284 & Zingiber officinale & Indonesia & 1 & 3 & MAFF \\
\hline 110 & MAFF 302500 & Manihot esculenta & Indonesia & 1 & 3 & MAFF \\
\hline 111 & MAFF 302510 & Lycopersicon esculentum & Indonesia & 1 & 3 & MAFF \\
\hline 112 & MAFF 302514 & Croton hirtus & Indonesia & nt & 3 & MAFF \\
\hline 113 & LEV22 & Lycopersicon esculentum & China & 1 & 3 & This study \\
\hline 114 & L178 & Solanum tuberosum & Nepal & 1 & 3 & NCAR \\
\hline 115 & MAFF 302487 & Manihot esculenta & Indonesia & 1 & 4 & MAFF \\
\hline 116 & 419-b-1-III & Zingiber officinale & Thailand & nt & 4 & T. Uematsu \\
\hline 117 & 412-c-1-I & Zingiber officinale & Thailand & nt & 4 & T. Uematsu \\
\hline 118 & $\mathrm{R} 277$ & Zingiber officinale & Australia & 4 & 4 & NCAR \\
\hline 119 & R292 & Morus sp. & China & 5 & 5 & NCAR \\
\hline
\end{tabular}


by repeated sampling with replacement, and the frequency with which a particular group was formed reflected the strength of the group.

RFLP analysis. Preparation of bacterial DNA was done according to the method of Cook et al. (3). Overnight cultures in CPG $(3 \mathrm{ml})$ were used. Extracted DNA was digested with the restriction enzyme EcoRI (Toyobo Co., Osaka, Japan). Digested DNA samples (approximately $1 \mu \mathrm{g}$ ) were run on a $0.8 \%$ agarose (type II medium EEO; Sigma Chemical) gel in $0.5 \times$ Tris-borate-EDTA buffer ( $89 \mathrm{mM}$ Tris- $\mathrm{HCl}, \mathrm{pH} 8.0,89 \mathrm{mM}$ boric acid, and $2 \mathrm{mM}$ EDTA) with electrophoresis at $6 \mathrm{~V} / \mathrm{cm}$ for $5 \mathrm{~h}$. Transfer of DNA fragments from agarose gel onto nylon membrane (Hybond-N+, Amersham International, Little Chalfont, England) and Southern hybridization using enhanced chemiluminescence labeling direct nucleic acid labeling and detection systems (Amersham International) were done according to the instructions of the manufacturer. After hybridization and stringency washes, signal was detected on a sheet of scientific imaging film (X-Omat; Eastman Kodak Co., Rochester, NY).

Two probes, $R$. solanacearum $h r p B$ and $h r p O$ genes controlling pathogenicity or hypersensitivity $(10,13)$, were amplified by PCR method and used. Primers were synthesized by Amersham Pharmacia Biotech. Primers HBL1 (5'-TCG CCA AAA GCG AAA ACT-3') and HBR2 (5'-TCG AGT CAG ATG CAT GAT-3') amplified a nearly full-length $h r p B$ gene from $R$. solanacearum MAFF 301520. Similarly, primers HOL1 (5'-AAC AGG AAC GAC GGA AAG-3') and HOR2 (5'-ATG GCC AAA AAG AAT GCA-3') amplified an internal region of the $h r p O$ gene. The $100-\mu$ reaction mixture $(10 \mathrm{mM}$ Tris- $\mathrm{HCl}, \mathrm{pH} 8.3,50 \mathrm{mM} \mathrm{KCl}$, $1.5 \mathrm{mM} \mathrm{MgCl}, 200 \mu \mathrm{M}$ each dNTP, 100 pmol primer, 2.5 unit of DNA polymerase Takara Taq, and $2 \mathrm{ng}$ of template DNA) was overlaid with $90 \mu \mathrm{l}$ of mineral oil (Sigma Chemical). Amplifications were performed on the thermocycler programmed as follows: an initial denaturation step of $94^{\circ} \mathrm{C}$ for $2 \mathrm{~min}$, followed by 40 cycles of $94^{\circ} \mathrm{C}$ for $1 \mathrm{~min}, 45^{\circ} \mathrm{C}$ for $2 \mathrm{~min}$, and $72^{\circ} \mathrm{C}$ for $3 \mathrm{~min}$, with a final extension step of $72^{\circ} \mathrm{C}$ for $5 \mathrm{~min}$. The amplified DNA was purified with an Easytrap kit (Takara Shuzo).

\section{RESULTS}

Pathogenicity and biovar determination. Seventy-four Japanese strains were tested for their pathogenicity and hypersensitivity, and were divided into four pathogenic groups (Table 2). Three groups (I to III) were pathogenic to tomato, eggplant, sweet pepper, and potato, and mostly corresponded to race 1 . Compatibility with tobacco (pathogenicity or hypersensitivity) differentiated group I from group II. Group III strains were characterized by weak pathogenicity to eggplant and potato. Group IV was pathogenic to potato, weakly pathogenic or nonpathogenic to tomato, and corresponded to race 3 .

Race 1 strains were isolated from various plants that included cucumber (Cucumis sativus L.), pumpkin (Cucurbita maxima Duch. $\times$ C. moschata Duch.), kalanchoe (Kalanchoe sp.), statice (Limonium sp.), bird-of-paradise (Strelitzia reginae Ait.), and five solanaceous crops (tomato, eggplant, sweet pepper, tobacco, and potato) across Japan. But race 3 strains were only isolated from potato (Tables 1 and 3).

Of the 74 strains tested, 19 were biovar N2, 24 were biovar 3 , and 31 were biovar 4 , respectively. The 11 race 3 strains belonged to biovar $\mathrm{N} 2$, whereas race 1 strains were not directly related to specific biovars (Tables 1 and 2). All strains produced nitrite from nitrate. Race 1 strains, except for two isolates (MAFF 211268 and 211281), produced nitrogen gas profusively from nitrate, but this was not observed for any race 3 strains. Biovar N2 strains were isolated from five solanaceous crops, whereas biovar 3 strains were isolated from a range of species including kalanchoe, statice, bird-of-paradise, and five solanaceous crops. Biovar 4 strains were mainly isolated from tomato, eggplant, and potato (Table 1)

All strains of biovar 4 and some of biovar 3 induced tobacco HR within $24 \mathrm{~h}$ and were weakly pathogenic or nonpathogenic to tobacco, whereas some biovar 3 and N2 strains caused a slow or spreading necrosis and were all pathogenic to tobacco. On the other hand, biovar N2 strains corresponding to race 3 caused a slow collapse of infiltrated area of tobacco leaves, but were nonpathogenic to tobacco (Table 2).

Fingerprint analysis of Japanese strains based on the repPCR method. rep-PCR genomic fingerprints of 74 Japanese strains were generated (Fig. 1). Similarity coefficients were calculated based on the fingerprints and a dendrogram was constructed (Fig. 2). The three primer sets REP, ERIC, and BOX, after duplicate analyses, defined 35 fingerprint types at the $95 \%$ similarity level (greater than this could not discriminate each strain with confidence). Each strain that differed by race or biovar represented a distinct fingerprint type (Fig. 1). The strains tested were separated into two main groups; one with all race 1 strains, and the other with only race 3 strains. Average similarity within race 1 and race 3 strains was 53 and 93\%, respectively, whereas

TABLE 2. Pathogenicity of Japanese strains of Ralstonia solanacearum

\begin{tabular}{|c|c|c|c|c|c|c|c|c|c|}
\hline \multirow[b]{2}{*}{ Code no. } & \multicolumn{5}{|c|}{ Pathogenicity ${ }^{\mathrm{a}}$} & \multirow[b]{2}{*}{ Tobacco HR ${ }^{b}$} & \multirow[b]{2}{*}{ Pathogenic group } & \multirow[b]{2}{*}{ Race } & \multirow[b]{2}{*}{ Biovar } \\
\hline & Tomato & Eggplant & Sweet pepper & Potato & Tobacco & & & & \\
\hline $3,7-12,25-55$ & $\mathrm{M}-\mathrm{H}$ & $\mathrm{M}-\mathrm{H}$ & $\mathrm{M}-\mathrm{H}$ & $\mathrm{M}-\mathrm{H}$ & $\mathrm{L}-0$ & HR & I & 1 & 3,4 \\
\hline $1,2,4,13-24,56-63$ & $\mathrm{M}-\mathrm{H}$ & $\mathrm{M}-\mathrm{H}$ & $\mathrm{L}-\mathrm{H}$ & $\mathrm{M}-\mathrm{H}$ & $\mathrm{M}-\mathrm{H}$ & $\mathrm{N}$ & II & 1 & $3, \mathrm{~N} 2$ \\
\hline $64-74$ & $\mathrm{~L}-0$ & 0 & 0 & $\mathrm{M}-\mathrm{H}$ & 0 & $\mathrm{C}$ & IV & 3 & $\mathrm{~N} 2$ \\
\hline
\end{tabular}

${ }^{a}$ Results based on average disease indices of two to four plants. Disease severity was observed 21 days after inoculation. $\mathrm{H}=$ high $(4.1$ to 5.0$)$, $\mathrm{M}=$ medium (2.6 to 4.0$), \mathrm{L}=$ low $(1.1$ to 2.5$)$, and $0=$ no symptom (1.0).

${ }^{\mathrm{b}} \mathrm{HR}=$ hypersensitive response within $24 \mathrm{~h} ; \mathrm{N}=$ slow or spreading necrosis on and after $48 \mathrm{~h}$; and $\mathrm{C}=$ slow collapse of infiltrated area on and after $48 \mathrm{~h}$.

TABLE 3. Grouping of Japanese strains of Ralstonia solanacearum on the basis of repetitive sequence-based polymerase chain reaction (rep-PCR) analysis

\begin{tabular}{|c|c|c|c|c|c|c|}
\hline rep-PCR group & No. of strains & Geographical origin ${ }^{a}$ & Race & Pathogenic group & Biovar & Original host \\
\hline A & 31 & Hk, Ho, Sh, Ky & 1 & I & 4 & Potato, tomato, eggplant, sweet pepper, pumpkin, cucumber \\
\hline B & 9 & Ho, Sh, Ky & 1 & II & $3, \mathrm{~N} 2$ & Tobacco, tomato, eggplant, sweet pepper \\
\hline $\mathrm{C}$ & 7 & $\mathrm{Ho}, \mathrm{Sh}$ & 1 & I & 3 & Tomato, eggplant, sweet pepper, statice \\
\hline $\mathrm{D}$ & 2 & Ky & 1 & III & 3 & Bird-of-paradise \\
\hline $\mathrm{E}$ & 11 & $\mathrm{Ho}, \mathrm{Sh}$ & 1 & II & 3 & Tobacco, kalanchoe \\
\hline $\mathrm{F}$ & 3 & Ho, Sh, Ky & 1 & II & 3 & Tobacco, tomato, eggplant \\
\hline $\mathrm{G}$ & 11 & Ho, Ky & 3 & IV & $\mathrm{N} 2$ & Potato \\
\hline
\end{tabular}

${ }^{\text {a }}$ Hk = Hokkaido (North); Ho = Honshu (Middle East-Middle West); Sh = Shikoku (Middle West); and Ky = Kyushu (West-South West). 
average similarity between race 1 and race 3 was $26 \%$. Race 1 strains were further subdivided into six (A through F) groups at the $80 \%$ similarity level (Fig. 2). At this level, each of the groups (except group D) consisted of plural fingerprint types possessing many common bands with high reproducibility (Fig. 1) and in-
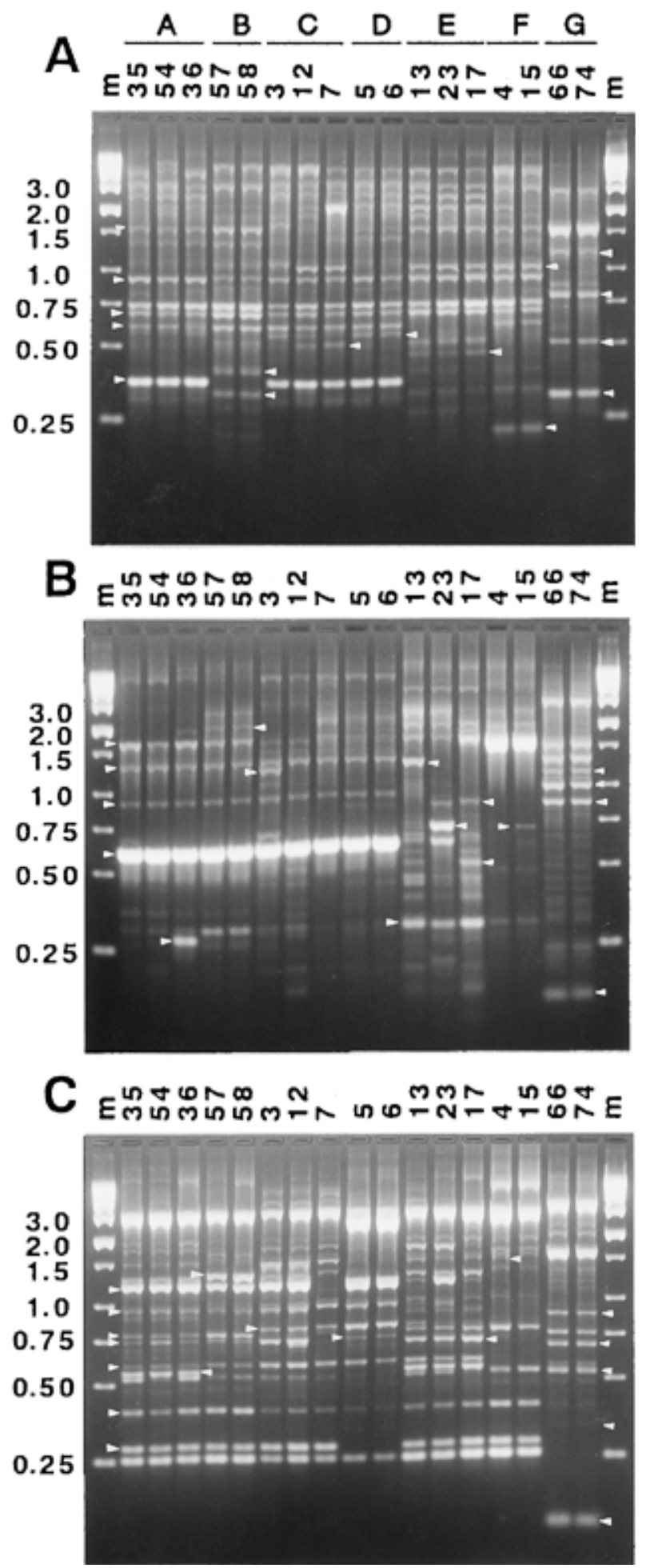

Fig. 1. Agarose gel showing representative patterns of Japanese strains generated by repetitive sequence-based polymerase chain reaction with $\mathbf{A}$, BOX; $\mathbf{B}$, enterobacterial repetitive intergenic consensus; and $\mathbf{C}$, repetitive extragenic palindromic primers. Numbers above lanes indicate strain code number (Table 1) and group (Fig. 2). Lane m, DNA molecular size marker (kilobase DNA ladder, Stratagene, La Jolla, CA). Sizes are indicated on the left in kilobase pairs. Arrowheads identify similarities or differences among selected strains or groups. cluded strains that differed in biovar, pathogenic group, or original host (Table 3 ). In race 1, each of biovars N2 and 4 was included in a single group and showed high similarity within each biovar. On the other hand, biovar 3 strains were divided into five groups (B through F) and showed low average similarity (55\%) among the strains.

Comparison of strains from Japan and other countries by the rep-PCR method. rep-PCR analysis was performed on 45 strains (representing six biovars and five races) from 15 countries (Table 1). The three primer sets defined 31 fingerprint types at the $95 \%$ similarity level and these types were compared with those of Japanese strains (Fig. 3). A dendrogram constructed based on repPCR data revealed two main clusters. Cluster 1 comprised biovar 3, 4, and 5 (race 1, 4, and 5) strains from Asia and Australia, and biovar 1 and N2 (race 1) strains from Reunion and Japan. Cluster 2 included biovar 1, 2, and N2 (race 1, 2, and 3) strains from 13 countries (Fig. 4). In cluster 2, average similarity within biovar 2 strains from eight countries (Belgium, Brazil, Egypt, Indonesia, Israel, Reunion, Sweden, and Thailand) and biovar N2 strains from Brazil were 94 and $65 \%$, respectively, whereas average similarity between biovar N2 strains from Brazil and Japan was $21 \%$ (Table 4).

Comparison of biovar $\mathrm{N} 2$ and 2 strains from Japan and other countries by RFLP analysis. To confirm the genetic differences among the strains based on rep-PCR data, RFLP analysis was performed on 29 biovar N2 strains from Japan and Brazil and 12 biovar 2 strains from the eight countries. The RFLP patterns observed in Southern blots of EcoRI-digested DNA probed with

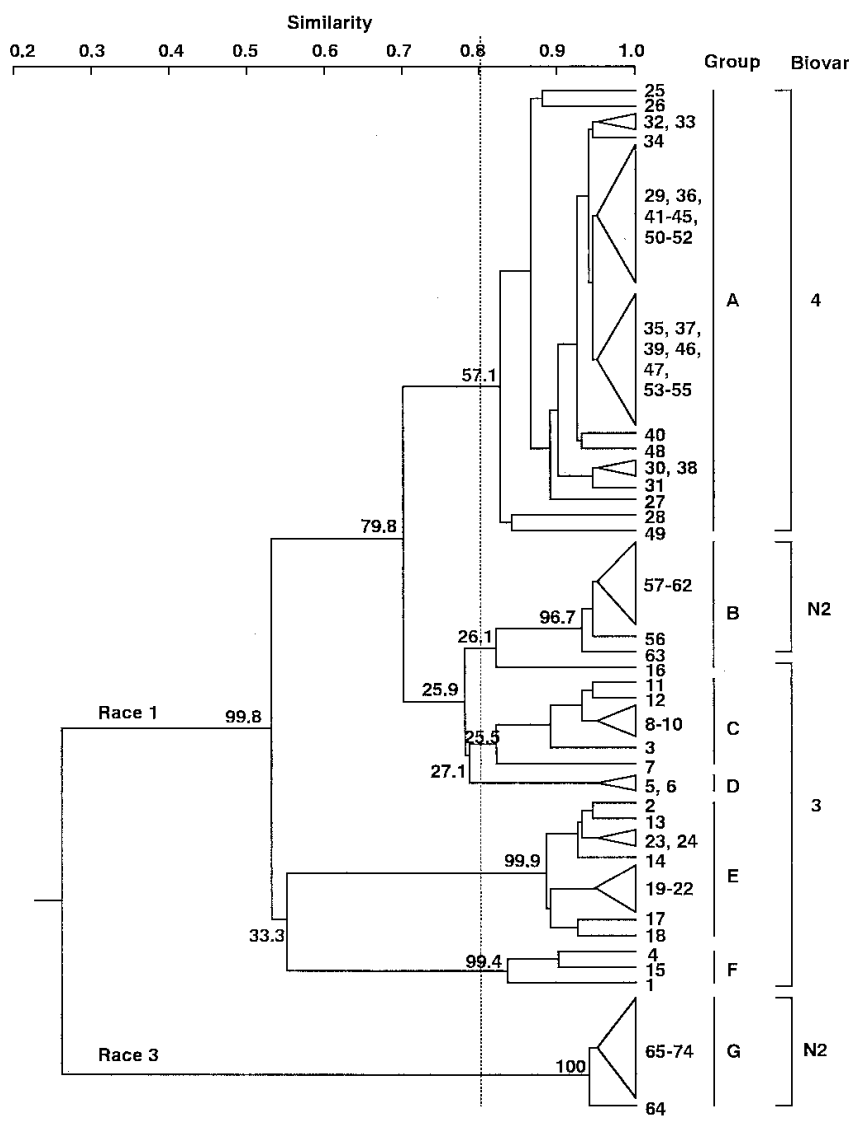

Fig. 2. Genetic diversity of 74 strains of Ralstonia solanacearum isolated in Japan. The 74 strains were divided into 35 fingerprint types, and seven groups at the $80 \%$ similarity level on the basis of repetitive sequence-based polymerase chain reaction. Similarity coefficients were calculated based on fingerprints by the Dice method. A dendrogram was constructed by the unweighted pair group method with arithmetic average clustering. Values on the branches represent the results of bootstrap analysis with 2,000 iterations. Strain code number (Table 1), group, and biovar are indicated to the right. 


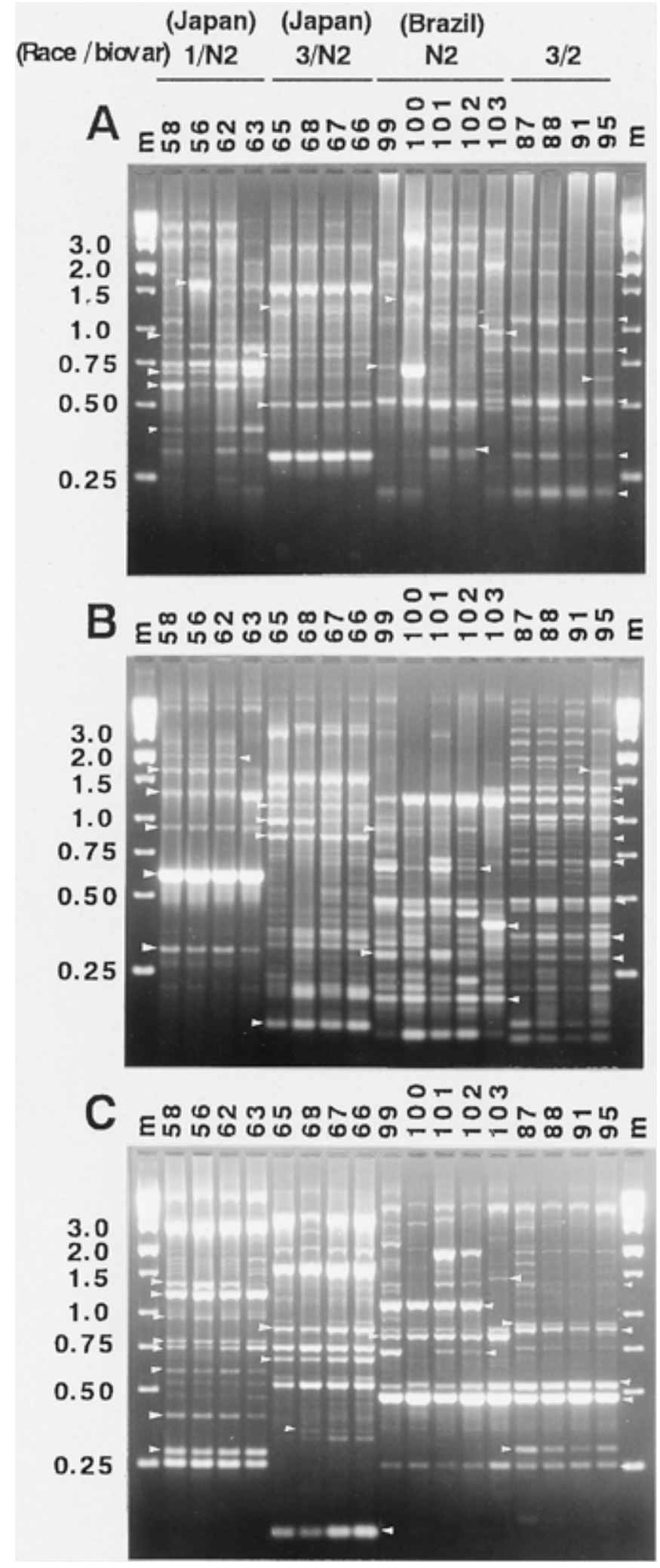

Fig. 3. Agarose gel showing representative patterns of biovar $\mathrm{N} 2$ and 2 strains of Ralstonia solanacearum generated by repetitive sequence-based polymerase chain reaction with $\mathbf{A}, \mathrm{BOX} ; \mathbf{B}$, enterobacterial repetitive intergenic consensus; and $\mathbf{C}$, repetitive extragenic palindromic primers. Numbers above lanes indicate strain code number (Table 1), race, biovar, and geographical origin. Lane m, DNA molecular size marker (kilobase DNA ladder, Stratagene, La Jolla, CA). Sizes are indicated on the left in kilobase pairs. Arrowheads identify similarities or differences among selected strains. $h r p O$ or $h r p B$ are shown in Figure 5A and B. Biovar 2 strains showed only one RFLP pattern, whereas biovar N2 strains showed four RFLP patterns, which enabled Japanese strains to be distinguished from Brazilian strains.

\section{DISCUSSION}

There are several studies concerning the pathogenicity and biochemical properties of Japanese strains of $R$. solanacearum with four biovars (1, 2, 3, and 4) and two races (1 and 3) reported $(24,33-37)$. The strains used in our experiments belong to biovars $\mathrm{N} 2,3$, and 4 or races 1 and 3 (Tables 1 and 2). Among them, biovar N2 strains showed phenotypic and pathogenic variability and belonged to two distinct races. Biovar 2 comprises several phenotypes. Marin and El-Nashaar (31) and French et al. (8) reported biochemical and pathogenic differences between highland (Andes) and lowland biovar 2 strains. Highland biovar 2 mainly affects potato and tomato and are equivalent to race 3 , whereas the lowland biovar 2 affected a wider range of plants (not equivalent to race 3) and was designated biovar N2 (new biovar 2) (11) or biovar 2T (tropical) (8). Biovar N2 is characterized by its use of trehalose, meso-inositol, and D-ribose, nitrite production from nitrate, and high pectolytic activity (17). The Japanese biovar 2 strains used in this study all utilized these three carbohydrates, produced nitrite from nitrate, and were almost identical to biovar N2. Katayama and Kimura (24) reported on the phenotypic char-

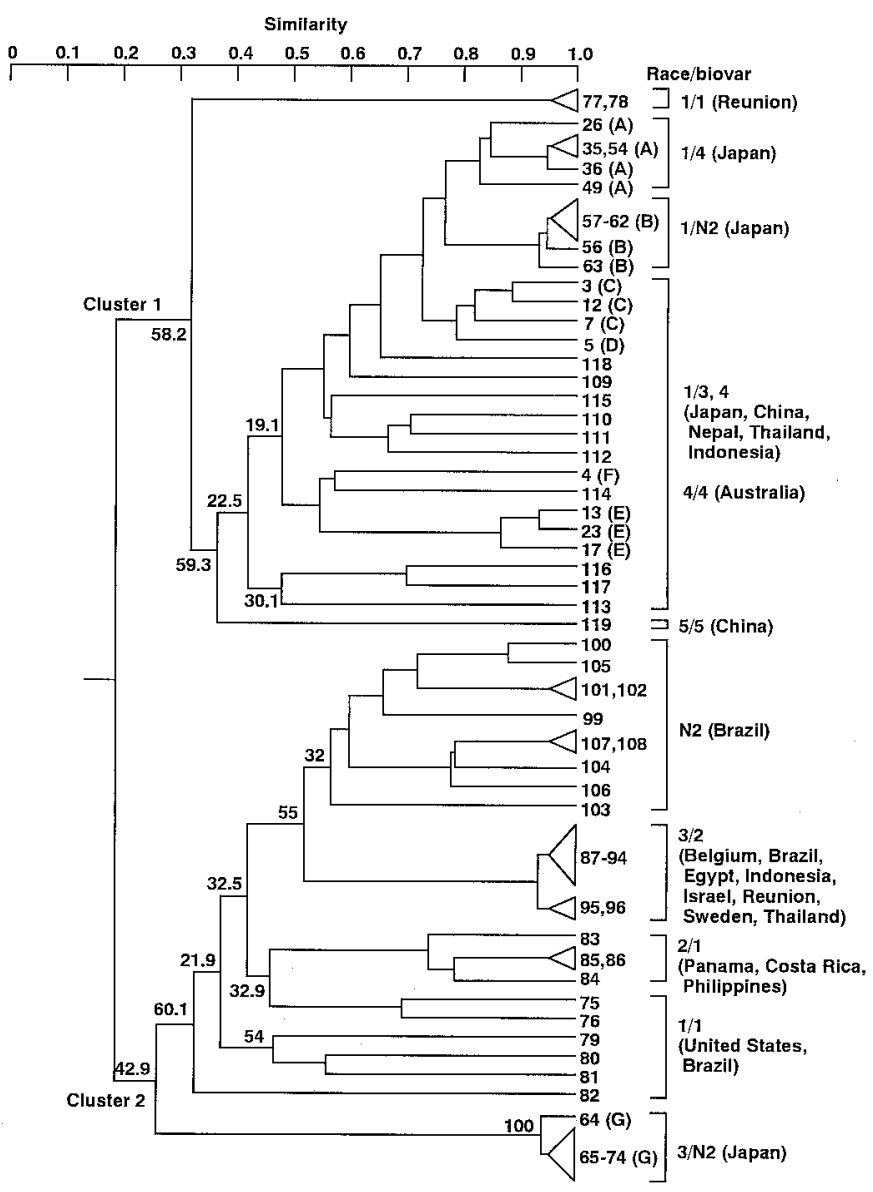

Fig. 4. Genetic diversity of 78 strains of Ralstonia solanacearum on the basis of repetitive sequence-based polymerase chain reaction. Similarity coefficient was calculated based on fingerprints by the Dice method. A dendrogram was constructed by the unweighted pair group method with arithmetic average clustering. Values on the branches represent the results of bootstrap analysis with 2,000 iterations. Strain code number (Table 1), group (in parenthesis), race, biovar, and geographical origin are indicated on the right. 
acteristics of biovar 2 strains isolated from potato in Nagasaki prefecture, Japan, and their results were almost identical to ours. Our pathogenicity tests and theirs (24) showed that these potato strains only affect potato and belong to race 3 (Table 2).

Biovar N2 strains from tomato, eggplant, sweet pepper, and tobacco were pathogenic to five solanaceous crops and almost corresponded to race 1 (Table 2). Okabe and Goto (35) reported that Japanese strains that utilize lactose but not mannitol as a sole carbon source (resembling biovar N2 or 2) are strongly pathogenic to tomato, tobacco, eggplant, and peanut. Our results confirm this observation. These strains produced nitrogen gas from nitrate and were different from Japanese potato strains and biovar N2 and 2 strains from other countries.

rep-PCR analysis has been used to differentiate several species and strains of phytopathogenic bacteria $(9,23,27-29,44)$. In this study, we used rep-PCR analysis to compare Japanese strains with other strains of $R$. solanacearum. Each primer set (REP, ERIC, or BOX) gave repeatable and distinct patterns (code no. 58 and 66 in Figs. 1 and 3). PCR-based techniques are usually subject to variations that reflect many factors, such as template and primer DNA concentrations and composition of the PCR buffer. We compared the band patterns that we observed (band sizes and intensities) with patterns previously observed by others and confirmed similarity for major bands. A dendrogram based on the rep-PCR fingerprints showed two main clusters; cluster 1 comprised all biovar 3, 4, and 5 strains, and cluster 2 included the majority of biovar 1, 2, and N2 strains (Fig. 4).

Cook et al. (3-5) assessed genetic diversity of $R$. solanacearum strains collected from many countries by the RFLP method and revealed two main divisions. Division I comprised all members of biovars 3, 4, and 5, and is thought to be of Asian origin. Division II contained all members of biovars 1, 2, and N2, and is thought to be of American origin. Taghavi et al. (47) analyzed 16S rRNA gene sequences of $R$. solanacearum and related species and identified two divisions that corresponded to the results obtained from RFLP analysis by Cook et al. (4).

Our rep-PCR results correspond closely with the divisions reported by Cook et al. (4). Our cluster 1 strains correspond to division I strains of Cook et al. (4), and our cluster 2 strains correspond to division II strains of Cook et al. (4).

$R$. solanacearum can be widely disseminated on vegetative propagating material (tomato, Heliconia, banana, and potato), and bacterial wilt of potato is spread locally and internationally by latently infected potato tubers (16). Buddenhagen (1) suggested that race 3 originated in the Andean region of South America where potato also originated and that the occurrence of race 3 outside South America was the result of human distribution of infected potato tubers. Several reports $(3,5,11,44)$ using DNAbased techniques (RFLP, rep-PCR, PFGE, etc.) support this hypothesis.

In Japan, race 3 strains have been reported in some potato fields but not in others (24). Our data based on rep-PCR fingerprints showed low average similarity between race 3 biovar N2 from Japan and biovar N2 from Brazil or race 3 biovar 2 from eight different countries (Table 4). RFLP analysis using hrpB or hrpO as a probe also differentiated the Japanese strains from these other strains (Fig. 5).

TABLE 4. Average similarity coefficient within and between biovar N2 and biovar 2 strains of Ralstonia solanacearum ${ }^{\mathrm{a}}$

\begin{tabular}{llcccc}
\hline & & \multicolumn{3}{c}{$\mathrm{N} 2$} & \\
\cline { 3 - 5 } Biovar & Geographic origin (rep-PCR) & Japan (B) & Japan (G) & Brazil & \\
\hline N2 & Japan (B) & 0.93 & $\ldots$ & $\ldots$ & $\ldots$ \\
N2 & Japan (G) & 0.24 & 0.93 & $\ldots$ & $\ldots$ \\
N2 & Brazil & 0.22 & 0.21 & 0.65 & $\ldots$ \\
2 & $\ldots$ & 0.22 & 0.31 & 0.52 & 0.94 \\
\hline
\end{tabular}

${ }^{\text {a }}$ Similarity coefficient calculated by the Dice method (7).
Several biovar N2 strains have been reported in Indonesia and Africa $(18,42,44,46)$. The genetic variability of Indonesian strains was shown by analyses of the rRNA gene $(42,47)$. The $16 \mathrm{~S}$ rRNA gene sequence from two race 3 biovar N2 Japanese strains was homologous to that of a race 1 biovar N2 strain (R780) from Indonesia (21). To decide whether the origin of Japanese race 3 is Indonesia or another area, further tests are needed.

Race 1 biovar N2 strains from Japan belong to cluster 1 (Fig. 4) with biovar 1 strains from Reunion (Africa), which showed a high similarity with biovar 3 and 4 strains in division I (41). Hayward et al. (18) reported that profuse gas production from nitrate is a valuable character for the identification of biovar 3, 4, and 5 strains. In cluster 1, all strains except two (code no. 116 and 117 ) provided profuse gas production from nitrate under anaerobic conditions (data not shown). Due to their nitrate metabolism and the rep-PCR data, race 1 biovar N2 strains from Japan might belong to the Asian origin group along with the biovar 3, 4, and 5 strains. However, to date, biovar N2 strains that atypically produce gas from nitrate have been reported only from Japan and a few African countries $(18,46)$. The genetic relationship between the Japanese and the African biovar N2 strains is not clear.

Biovars 3 and 4 of $R$. solanacearum are homogeneous and distinct from other biovars of this species based on molecular analyses and physiological characteristics $(3-5,26,38,47)$. However, analysis of Japanese strains based on rep-PCR fingerprint data showed that biovar 3 and 4 strains each belonged to distinct groups. Biovar 4 strains are homogeneous and belong to one group corresponding to one pathogenic group at the $80 \%$ similarity level. However, biovar 3 strains showed low average similarity among the strains and are divided into five groups that differ in pathogenic group or original host (Table 3; Fig. 2). Okabe and Goto (35) also reported that Japanese strains that utilize lactose and mannitol (probably corresponding to biovar 3) could be divided into 10 distinct groups that differ in pathogenicity and bacteriophage sensitivity. Phenotype and rep-PCR pattern may be correlated. Although our pathogenicty test results provide preliminary information concerning resistance/susceptibility levels for this wide range of strains, further large-scale tests are required for quantitative assessment of resistance/susceptibility.
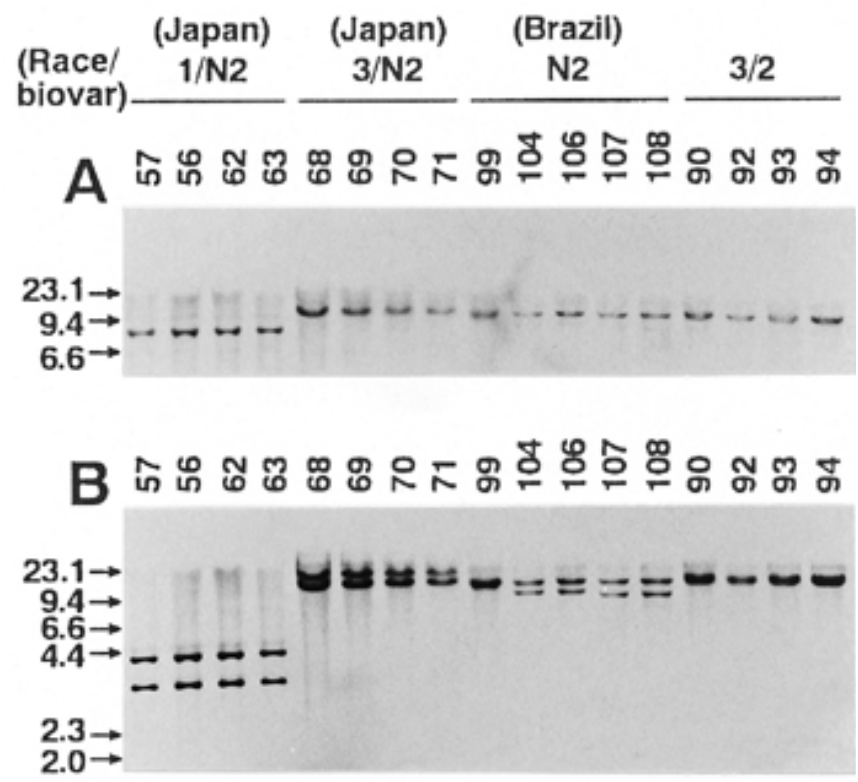

Fig. 5. Southern blot analysis of total DNA from biovar N2 and 2 strains of Ralstonia solanacearum. The probe was $\mathbf{A}, h r p O$ or $\mathbf{B}, h r p B$. Total DNA was digested with EcoRI and subjected to electrophoresis on a $0.8 \%$ agarose gel. Numbers above lanes indicate strain code number (Table 1), race, biovar, and geographical origin. Sizes of marker DNA fragments (HindIII-digested $\lambda$ DNA) are indicated on the left in kilobase pairs. 
In the last 15 years, 13 new hosts (pumpkin, statice, kalanchoe, bird-of-paradise, etc.) of $R$. solanacearum have been reported in Japan $(6,40)$. However, the origin of these new strains is unknown. The results presented here should help to clarify the genetic relationships among these strains and may contribute to the elucidation of their origin.

In a pumpkin field in Okayama prefecture, Japan, severely wilted plants were observed in close proximity to infected eggplant (6). rep-PCR results showed a high similarity between pumpkin and eggplant isolates (Table 3; Fig. 2), with a few of the eggplant isolates being pathogenic on pumpkin (data not shown). Our results also show that statice and kalanchoe isolates are closely related to tomato, eggplant, and sweet pepper isolates (group C) and tobacco isolates (group E), respectively. However, bird-of-paradise isolates consist of a single group (D) corresponding to one specific pathogenic group (III), and the relationship between these strains and other isolates is not clear.

In Japan, most strains from recently identified hosts are biovar 3 (6). This biovar has a wide host range $(14,16)$ and has been isolated from various plants in Japan $(6,40)$. Our results suggest that biovar 3 strains are phenotypically and genetically variable and have the potential to be compatible with more hosts than the other Japanese biovars. To confirm this hypothesis, further analysis with isolates from other hosts is under investigation.

\section{ACKNOWLEDGMENTS}

We thank all of those who contributed strains used in this study and D. A. Vaughan for critical review of the manuscript.

\section{LITERATURE CITED}

1. Buddenhagen, I. 1985. Bacterial wilt revisited. Pages 126-143 in: Bacterial Wilt Disease in Asia and the South Pacific. G. J. Persley, ed. Aust. Cent. Int. Agric. Res. Proc. 13.

2. Buddenhagen, I., Sequeira, L., and Kelman, A. 1962. Designation of races in Pseudomonas solanacearum. (Abstr.) Phytopathology 52:726.

3. Cook, D., Barlow, E., and Sequeira, L. 1989. Genetic Diversity of Pseudomonas solanacearum: Detection of restriction fragment length polymorphisms with DNA probes that specify virulence and the hypersensitive response. Mol. Plant-Microbe Interact. 2:113-121.

4. Cook, D., Barlow, E., and Sequeira, L. 1991. DNA probes as tools for the study of host-pathogen evolution: The example of Pseudomonas solanacearum. Pages 103-108 in: Advances in Molecular Genetics of Plant-Microbe Interactions. Vol. 1. H. Hennecke and D. P. Verma, eds. Kluwer Academic Publishers, Dordrecht, the Netherlands.

5. Cook, D., and Sequeira, L. 1994. Strain differentiation of Pseudomonas solanacearum by molecular genetic methods. Pages 25-34 in: Bacterial Wilt, the Disease and Its Causative Agent, Pseudomonas solanacearum. A. C. Hayward and G. L. Hartman, eds. CAB International, Wallingford, U.K.

6. Date, H. 1995. New hosts of bacterial wilt in Japan. (In Japanese.) Shokubutu Boeki (Plant Prot.) 49:249-252.

7. Dice, L. R. 1945. Measurement of the amount of ecologic association between species. Ecology 26:297-302.

8. French, E. R., Aley, P., Torres, E., and Nydegger, U. 1993. Diversity of Pseudomonas solanacearum in Peru and Brazil. Pages 70-77 in: Bacterial Wilt. G. L. Hartman and A. C. Hayward, eds. Aust. Cent. Int. Agric. Res. Proc. 45.

9. Frey, P., Smith, J. J., Albar, L., Prior, P., Saddler, G. S., Trigalet-Demery, D., and Trigalet, A. 1996. Bacteriocin typing of Burkholderia solanacearum race 1 of the French West Indies and correlation with genomic variation of the pathogen. Appl. Environ. Microbiol. 62:473-479.

10. Genin, S., Gough, C. L., Zischek, C., and Boucher, C. A. 1992. Evidence that the $h r p B$ gene encodes a positive regulator of pathogenicity genes from Pseudomonas solanacearum. Mol. Microbiol. 6:3065-3076.

11. Gillings, M., and Fahy, P. 1993. Genetic diversity of Pseudomonas solanacearum biovar 2 and $\mathrm{N} 2$ assessed using restriction endonuclease analysis of total genomic DNA. Plant Pathol. 42:744-753.

12. Gilson, E., Clement, J. M., Brutlag, D., and Hofnung, M. 1984. A family of dispersed repetitive extragenic palindromic DNA sequences in E. coli. Eur. Mol. Biol. Organ. J. 3:1417-1421.

13. Gough, C. L., Genin, S., Lopez, V., and Boucher, C. A. 1993. Homology between the HrpO protein of Pseudomonas solanacearum and bacterial proteins implicated in a signal peptide-independent secretion. Mol. Gen. Genet. 239:378-392.

14. Hayward, A. C. 1964. Characteristics of Pseudomonas solanacearum. J. Appl. Bacteriol. 27:265-277.

15. Hayward, A. C. 1976. Some techniques of importance in the identification of Pseudomonas solanacearum. Pages 137-142 in: Proc. Int. Plan. Conf. Workshop Ecol. Control Bact. Wilt Caused by Pseudomonas solanacearum, 1st. L. Sequeira and A. Kelman, eds. North Carolina State University, Raleigh.

16. Hayward, A. C. 1991. Biology and epidemiology of bacterial wilt caused by Pseudomonas solanacearum. Annu. Rev. Phytopathol. 29:65-87.

17. Hayward, A. C. 1994. Systematics and phylogeny of Pseudomonas solanacearum and related bacteria. Pages 123-135 in: Bacterial Wilt: The Disease and Its Causative Agent, Pseudomonas solanacearum. A. C. Hayward and G. L. Hartman, eds. CAB International, Wallingford, U.K.

18. Hayward, A. C., El-Nashaar, H. M., Nydegger, U., and De Lindo, L. 1990. Variation in nitrate metabolism in biovars of Pseudomonas solanacearum. J. Appl. Bacteriol. 69:269-280.

19. He, L., Sequeira, L., and Kelman, A. 1983. Characteristics of strains of Pseudomonas solanacearum from China. Plant Dis. 67:1357-1361.

20. Hendrick, C. A., and Sequeira, L. 1984. Lipopolysaccharide-defective mutants of the wilt pathogen Pseudomonas solanacearum. Appl. Environ. Microbiol. 48:94-101.

21. Horita, M., and Tsuchiya, K. 2000. Comparative analysis of Japanese and foreign strains of Ralstonia solanacearum based on 16S rRNA gene sequences. J. Gen. Plant Pathol. 66:132-137.

22. Hulton, C. S. J., Higgins, C. F., and Sharp, P. M. 1991. ERIC sequences: A novel family of repetitive elements in the genomes of Escherichia coli, Salmonella typhimurium and other enterobacteria. Mol. Microbiol. 5:825-834.

23. Jaunet, T. X., and Wang, J.-F. 1999. Variation in genotype and aggressiveness diversity of Ralstonia solanacearum race 1 isolated from tomato in Taiwan. Phytopathology 89:320-327.

24. Katayama, K., and Kimura, S. 1986. Ecology and protection of bacterial wilt of potato: I. Ecology and strains of Pseudomonas solanacearum. (In Japanese, with English summary.) Bull. Nagasaki Pref. Agric. Exp. Stn. 14:1-30.

25. Kelman, A. 1954. The relationship of pathogenicity of Pseudomonas solanacearum to colony appearance on a tetrazolium medium. Phytopathology 44:693-695.

26. Li, X., Dorsch, M., Del Dot, T., Sly, L. I., Stackebrandt, E., and Hayward, A. C. 1993. Phylogenetic studies of the rRNA group II pseudomonads based on $16 \mathrm{~S}$ rRNA sequences. J. Appl. Bacteriol. 74:324-329.

27. Louws, F. J., Bell, J., Medina-Mora, C. M., Smart, C. D., Opgenorth, D., Ishimaru, C. A., Hausbeck, M. K., de Brujin, F. J., and Fulbright, D. W. 1998. rep-PCR mediated genomic fingerprinting: A rapid and effective method to identify Clavibacter michiganensis. Phytopathology 88: 862-868.

28. Louws, F. J., Fulbright, D. W., Stephens, C. T., and de Brujin, F. J. 1994. Specific genomic fingerprint of phytopathogenic Xanthomonas and Pseudomonas pathovars and strains generated with repetitive sequences and PCR. Appl. Environ. Microbiol. 60:2286-2295.

29. Louws, F. J., Fulbright. D. W., Stephens, C. T., and de Brujin, F. J. 1995. Differentiation of genomic structure by rep-PCR fingerprinting to rapidly classify Xanthomonas campestris pv. vesicatoria. Phytopathology 85:528-536.

30. Lozano, J., and Sequeira, L. 1970. Differentiation of races of Pseudomonas solanacearum by a leaf infiltration technique. Phytopathology 60:833-838.

31. Marin, J. E., and El-Nashaar, H. M. 1993. Pathogenicity and new phenotypes of Pseudomonas solanacearum from Peru. Pages 78-84 in: Bacterial Wilt. G. L. Hartman and A. C. Hayward, eds. Aust. Cent. Int. Agric. Res. Proc. 45.

32. Martin, B., Humbert, O., Camara, M., Guenzi, E., Walker, J., Mitchell, T., Andrew, P., Prudhomme, M., Alloing, G., Hakenbeck, R., Morrison, D. A., Boulnois, G. J., and Claverys, J.-P. 1992. A highly conserved repeated DNA element located in the chromosome of Streptococcus pneumoniae. Nucleic Acids Res. 20:3479-3483.

33. Okabe, N. 1954. Studies on Pseud. solanacearum: V. Antagonism among the strains of $P$. solanacearum. Bull. Fac. Agric. Shizuoka Univ. 4:37-40.

34. Okabe, N., and Goto, M. 1953. Studies on Pseud. solanacearum: I. Classification of the strains by bacteriophages and virulence of the strains. Bull. Fac. Agric. Shizuoka Univ. 3:52-80.

35. Okabe, N., and Goto, M. 1961. Studies on Pseudomonas solanacearum: XI. Pathotypes in Japan. Bull. Fac. Agric. Shizuoka Univ. 11:25-42.

36. Ozaki, K., and Kimura, T. 1992. Studies on biovar of Pseudomonas 
solanacearum from solanaceous plants and its several characteristics. (In Japanese, with English summary.) Bull. Chugoku Natl. Agric. Exp. Stn. 10:41-48.

37. Ozaki, K., and Kimura, T. 1992. Grouping of Pseudomonas solanacaerum on the basis of pathogenicity to Solanum plants. (In Japanese, with English summary.) Bull. Chugoku Natl. Agric. Exp. Stn. 10:49-58.

38. Palleroni, N., and Doudoroff, M. 1971. Phenotypic characterization and deoxyribonucleic acid homologies of Pseudomonas solanacearum. J. Bacteriol. 107:690-696.

39. Pegg, K., and Moffet, M. 1971. Host range of the ginger strain of Pseudomonas solanacearum in Queensland. Aust. J. Exp. Agric. Anim. Husb. 11:696-698.

40. Phytopathological Society of Japan. 2000. Common Names of Plant Diseases in Japan. Japan Plant Protection Association, Tokyo.

41. Poussier, S., Vandewalle, P., and Luisetti, J. 1999. Genetic diversity of African and worldwide strains of Ralstonia solanacearum as determined by PCR-restriction fragment length polymorphism analysis of the hrp gene region. Appl. Environ. Microbiol. 65:2184-2194.

42. Seal, S. E., Taghavi, M., Fegan, N., Hayward, A. C., and Fegan, M. 1999. Determination of Ralstonia (Pseudomonas) solanacearum rDNA subgroups by PCR tests. Plant Pathol. 48:115-120.

43. Smith, E. F. 1896. A bacterial disease of tomato, pepper, eggplant, and Irish potato (Bacillus solanacearum nov. sp.). U.S. Dep. Div. Veg. Phys. Path. Bull. 12:1-28.
44. Smith, J. J., Offord, L. C., Holderness, M., and Saddler, G. S. 1995. Genetic diversity of Burkholderia solanacearum race 3 in Kenya. Appl. Environ. Microbiol. 61:4263-4268.

45. Sneath, P. H. A., and Sokal, R. R. 1973. Numerical Taxonomy. W. H. Freeman \& Co., San Francisco.

46. Swanepoel, A. E., and Young, B. W. 1988. Characteristics of South African strains of Pseudomonas solanacearum. Plant Dis. 72:403-405.

47. Taghavi, M., Hayward, C., Sly, L. I., and Fegan, M. 1996. Analysis of the phylogenetic relationships of strains of Burkholderia solanacearum, Pseudomonas syzygii, and the Blood disease bacterium of banana based on 16S rRNA sequences. Int. J. Syst. Bacteriol. 46:10-15.

48. Winstead, N. N., and Kelman, A. 1952. Inoculation techniques for evaluating resistance to Pseudomonas solanacearum. Phytopathology 42:628-634.

49. Yabuuchi, E., Kosako, Y., Yano, I., Hotta, H., and Nishiuchi, Y. 1995. Transfer of two Burkholderia and an Alcaligenes species to Ralstonia gen. nov.: Proposal of Ralstonia picketii (Ralston, Palleroni and Doudoroff 1973) comb. nov., Ralstonia solanacearum (Smith 1896) comb. nov. and Ralstonia eutropha (Davis 1969) comb. nov. Microbiol. Immunol. 39:897-904.

50. Yap, I., and Nelson, R. J. 1996. Winboot: A program for performing bootstrap analysis of binary data to determine the confidence limits of UPGMA-based dendrograms. IRRI Discussion Paper Series 14. International Rice Research Institute, Manila, Philippines. 